\title{
Management of Innovation Processes In the Health Economy System of Ukraine
}

\author{
ZAKHARCHENKO PAVLO V. \\ Berdyansk State Pedagogical University \\ 4 Shmidta str., Berdyansk, UKRAINE \\ GLAZOVA YANA V. \\ Berdyansk State Pedagogical University \\ 4 Shmidta str., Berdyansk, UKRAINE \\ ZHVANENKO SVITLANA A. \\ Berdyansk State Pedagogical University \\ 4 Shmidta str., Berdyansk, UKRAINE \\ KOSTENKO GANNA P. \\ Berdyansk State Pedagogical University \\ 4 Shmidta str., Berdyansk, UKRAINE \\ KUCHER STANISLAV F. \\ Berdyansk State Pedagogical University \\ 4 Shmidta str., Berdyansk, UKRAINE \\ MUKHIN VIKTOR S. \\ Berdyansk State Pedagogical University \\ 4 Shmidta str., Berdyansk, UKRAINE
}

\begin{abstract}
In today's health economics, resort and recreation is one of the most lucrative areas of the economy. Ukraine has a strong resort and recreational potential, the effective development of which can bring real economic benefits. This requires the formation of a systemic strategy for the development of such systems, an integral part of which are innovations. The purpose of the article is to analyze and develop methods for managing innovations in the health economy of Ukraine with its further development. The author's concept, which is based on the methods of economic dynamics, multicriteria optimization and optimal management, is used as a methodological approach. That is the first time the proposed concept has been used to analyze, forecast and formulate innovation policy and the development of innovation processes in the health economy. It allows to build predictive scenarios of innovation development with a high degree of accuracy compared to existing approaches, and is more adequate and universal in a pandemic. As a result of the research the concept of innovation development strategy as a certain period of cyclical dynamics was substantiated, and scenarios of influence, development and implementation of innovations were obtained. The proposed approach provides an opportunity to consider the development of the health economy and, in particular, resort and recreational systems as a process of transformational change of innovation strategies. On this basis, a model is built that allows for a scenario description of the transformation of innovative strategies of resort and recreational systems. The proposed model allows for choosing an innovation policy, i.e. at what point in time to begin the implementation of a new resort and recreational technology, which includes decisions on the feasibility of its implementation in general. The simulation results can be used to form a new modern strategy for the development of the health economy in Ukraine.
\end{abstract}

Key-Words: health economics, resort and recreation industry, innovation processes, innovation development, management of innovation processes, innovation strategy models.

Received: January 27, 2021. Revised: June 30, 2021. Accepted: July 1, 2021. Published: July 9, 2021. 


\section{Introduction}

In today's health economy, tourism, resort and recreation are one of the most profitable industries of the economy. For many countries, they have become not only a constantly growing source of financial income, but also due to the attraction of millions of tourists, the infrastructure of these areas is beginning to develop more actively, creating new additional jobs. Ukraine has a strong resort and recreational potential, the effective development of which can bring real economic benefits. Therefore, the recreational industry in the process of market transformation of the economy should take one of the leading places in the structure of the economic complex of the country $[1,2,3]$.

However, despite the rich resort and recreational resource base and a wide network of tourism entities, Ukraine still lacks a clear modern strategy for the development of resorts that meets global and European standards. As a rule, strategies of functioning and development of resort and recreational complexes have local character and are focused, first of all, on the rest and amusement and, only then on restoration and treatment. As a result, in terms of the level of development of the resort and tourism industry, Ukraine takes one of the last places in Europe, and the degree of compliance of its resort sector with environmental standards, cultural and historical heritage is quite low.

Decreased real incomes, weakened coordination of complexes, as well as lack of control over the use of natural healing resources have led to a number of negative aspects, which is expressed in a reduction in the number of visitors by more than $50 \%$, a significant reduction in bed capacity, high prices for resort and recreational products. The result was a difficult socio-economic situation of national resorts, which for many years defined the strategy of survival as the main direction of its development. Therefore, one of the current areas of research in this filed is the development of models of innovative development of resorts based on modern market requirements $[4,5,6,7]$. Thus, the identification of determinants and modern mechanisms for managing sustainable development through innovation is becoming increasingly apparent. The purpose of the article is to analyze and develop methods for managing innovation in the health economy of Ukraine with its further development.

Trends in world economic development show that currently more than half of the gross domestic product is produced in the services sector. More than $40 \%$ of direct investment in the world economy is accounted for by trade, banking and financial services, the resort industry and tourism. World practice shows that the resort and tourism industry in terms of profitability and dynamic development is second only to the extraction and refining of oil and gas. According to the World Tourism Organization (UNWTO), the resort and tourism business provides $10 \%$ of the turnover of the services market, it accounts for $7 \%$ of total world investment and 5\% of all tax revenues [8,9]. Therefore, the national resort and tourism sector should be considered as one of the main components which fills the budgets, which will contribute to the development of innovation processes, the creation of new resort and tourism products and technologies.

The high level of competition in the market of resort and recreational products, the need for qualitative changes in the organization of management to meet consumer demand more flexibly, the need for modern recreational products and increase the level of service, require Ukrainian resorts to expand innovation, which is aimed at optimal development of recreational potential and will allow to create a strategy of regional innovative development and the domestic industry of resorts and tourism $[10,11]$.

\section{Literature review}

The concept of "innovation" as an economic category was introduced into scientific circulation by the Austrian economist J. Schumpeter [12]. He first considered the question of new combinations of factors of production and identified five changes in development, i.e. issues of innovation. A significant contribution to the study of the importance of innovation was made by the famous Ukrainian scientist-economist M.D. Kondratiev, who proposed the theory of long economic cycles. According to his theory, the transition to a new cycle of development is associated with technical progress, which is expressed in the emergence of inventions and discoveries that affect production and consumption. In this case, the greatest importance in the economic transformation of society belongs to innovation $[13,14]$.

German economist G. Mensch introduced the concept of "disruptive innovations", when the potential of which is the prospect of stagnation in economic development, which he described as a "technological stalemate" [15]. Thus, G. Mensch linked the cyclical nature of economic development with the cyclical nature of innovation. The study of the specifics of innovations allowed him to propose their assignment to three groups competing for resources: disruptive innovations, improving and pseudo-innovations, which successively replace each other. At the same time, it is characteristic that 
there is the formation of discrete groups or clusters in the phase of depression. This is due to the fact that in this period of economic development the efficiency of investment in traditional areas is sharply decreased, and the introduction of disruptive innovations is the only opportunity for profitable investment.

There is a theoretical and practical consideration of innovation in the works of A. Kleinhet [16], S. Kuznets [17], R. Coombs [18], K. Freeman [19] and others $[20,21]$. Preferring the study of cyclical problems in economic development, periodization of scientific and technological revolutions, the authors of these works are unanimous about the crucial role of innovation in economic growth. In turn, economic growth is an integral part of society.

The evolutionary approach in the study of innovation processes is based on the work of $\mathrm{R}$. Nelson and S. Winter, as well as other researchers of the principles of evolutionary economics [22]. The term "evolutionary modeling", introduced by the authors, involves the use of Darwin's principles to analyze the behavior of the firm in a competitive environment. This suggests the existence in the economic environment of an inherent desire to selforganize the process of development, search and implementation of innovations. At the same time, evolutionary self-organizing innovation processes are mainly formed intuitively, which does not allow to predict with sufficient accuracy the prospects of their actions on economic systems. Understanding this leads to the conclusion that in developed countries, government and business structures are developing mechanisms to support market-oriented research and accelerate the commercialization of their results, which leads to increased competitiveness of individual industries and territories, and the state as a whole. Thus, the innovation sphere receives significant investment resources that allow to renew the productive forces, fixed capital, to conduct further research and development.

In general, it is necessary to note that the analysis of these concepts can provide a methodological basis for the defining of the role of innovation and innovation process in economic development. At the same time, despite the significant number of studies on the health economy [23, 24, 25] and resort and recreational systems, the idea of the mechanisms of innovation in general and in some aspects is fragmentary and not systematic. The current situation has necessitated the creation of modern tools in connection with the undeniable importance of the problem of innovation for the development of the national health economy and, in particular, the resort and recreational sphere.

\section{Methodological aspect of the research of management of innovative processes in the health economics}

Carrying out of innovative activity by any economic agent assumes presence of certain characteristics which will become a basis of development and introduction of innovations. It is also necessary to have investment resources that can be used for this purpose. In this regard, it is advisable to consider the concept of innovation and investment potential, as a basis for innovation and investment activities, in organic unity, considering it in the context of coevolutionary development.

Let's consider modern approaches to determining these economic mechanisms. The concept of innovative potential of an enterprise, resort complex, region or country as a whole has been developed since the early 1980s, refined as a result of theoretical, methodological and empirical research and has not lost its relevance today.

Scientific approaches to defining the essence of innovation potential, its in-depth and comprehensive study are presented in [26, 27], where innovation potential is understood as the number of economic resources potentially possible to be used at a given time by society to ensure its development. From the microeconomic point of view, it is considered as a set of logistical, informational, human and other resources of a business entity.

It seems insufficiently substantiated the reduction of the innovative potential of the resort and recreational system only to a set of different resources. However, the existence of such approach makes it possible to describe the innovation potential based on indicators of capital security, energy security, as well as to indicate the qualifications of staff and managers. At the same time, the traditional concept of "resources" does not allow to apply it to the means and factors that shape the innovation process, that necessarily have the characteristics of novelty and originality, the ability to reproduce not only at the existing level with its inherent characteristics, but and in the long run, at a higher level. However, the question remains open: how these factors form a holistic system that is potentially capable of innovation. In our opinion, it is objective to define the innovation potential as an ability of the resort and recreational system to effectively attract new technologies into economic turnover $[28,29]$. It is assumed that the innovation potential consists of four parts: 
availability of own and acquired medical and technological developments and inventions;

the state of infrastructural capabilities of the resort and recreational system, ensuring the passing of innovations of all stages of the innovation cycle, turning them into innovation;

external and internal factors, that reflect the interaction of innovation potential with other parts of the total potential of a resort, influencing the success of implementation of the innovation cycle;

the level of innovation culture, which characterizes staff acceptance of innovations, their willingness and ability to implement new ideas in the form of innovations.

It should be noted that the more resources the resort and recreation system has, the higher will be its innovative potential. But in practice this thesis is not always confirmed. Sometimes, a large resort and recreation complex, which has significant resources, has less innovative potential compared to a small team of innovators. The presence of such dissonance is the root cause of venture entrepreneurship. This is confirmed by the analysis of innovation activity of large and small firms in economically developed countries, which demonstrates the presence of both advantages and disadvantages in the creation and implementation of innovations.

Thus, the existence of parity between large and small businesses in the health economy and, in particular, in the resort and recreational economy, will ensure the greatest efficiency of innovation processes. This is confirmed by the complications and growing complexity of the investment itself, resulting in patterns of innovation.

In competitive conditions and an uncertain external environment, the achievement of economic goals by the resort and recreational system is based on its specific qualities and the qualities of the management system (multiplicity of reactions). It can be argued that one of the main system qualities is the ability to innovate [30]. By this concept we will mean the ability of the resort and recreational system to be updated, i.e. to carry out internal organizational processes of restructuring according to the criteria: rhythm, manufacturability, minimum cost. In other words, the ability to innovate implements the concept of construction of the resort and recreational system, which is depended on the external conditions.

The ability to innovate is based on the ability to master two types of innovation. On the one hand, these are medical and technological innovations related to the renewal of the medical and technological component of the resort and recreational system. Another important component of innovation is social innovation. The scientific and instrumental basis of such innovations is a set of mastered social technologies. It is known that the effectiveness of resort and recreational innovations is determined by a system of measures to organize the work of the staff, to change the set of patterns of their behavior to meet the technological requirements of this innovation. In addition, the technical tools of social innovation include methods of forming corporate values, corporate culture.

\section{Modeling of management of innovative processes in the system of health economic}

In the modern resort and recreational economy, the role of innovation has grown significantly. It is increasingly becoming major drivers of economic growth. The growing role of innovation is due, firstly, to the very nature of market relations, and secondly, the need for deep qualitative changes in the resort and tourism sector of Ukraine in order to enter the trajectory of sustainable growth. In particular, the concept of building a market economy in Ukraine is based on the postulate that the main factor of competitiveness is innovation, embodied in new scientific knowledge, technologies and services. Practice shows that the introduction of new technologies has always had a positive impact on economic growth and living standards, which, in a new round of development, created the conditions for the development and implementation of other new innovations. The analysis of the current state of the resort and tourism industry in Ukraine demonstrates a significant increase in tourist flows, construction of new medical centers, investment in health resorts. This situation has led to the application of European standards based on the implementation of innovations.

Without the application of innovations, it is now almost impossible to create competitive products with a high degree of knowledge and novelty. Thus, in a market resort and recreational economy, innovation is an effective means of competition, as they lead to the creation of new needs and lower production costs, to increase investment and to improve the image of the manufacturer of a new product, to open and capture new markets. In other words, innovations should be considered only as an integral part of the competitive market, they had and make sense in an environment where they contribute to the competitiveness of both the created resort and recreational product and the national resort and tourism complex as a whole. 
Due to the high degree of importance of the innovation capability, let's perform modeling of the behavior of the resort and recreational system in the conditions of the implementation of innovations. To this end, we modify the model of the choice of innovation policy [31] by the resort and recreational system in accordance with the conditions of the innovative economy. Assume that the dynamics of the development $n>1$ of recreational technologies on the planned horizon $T$, which is fixed and known, is consired.

The dynamics of technology development $i$ is described by the following differential eq 1 $x_{i}^{\prime}=\left\{f_{i}\left(x_{i-1}\left(t_{i}\right), u_{i}(t) x_{i}(t)\left[P_{i}-x_{i}(t)\right]\right\} \Omega\left(t \geq t_{i}\right)\right.$

where:

$f_{i}\left(x_{i-1}\left(t_{i}\right)\right.$ - previous state of development of recreational technologies,

$u_{i}(t)$ - management, which can be seen as an investment in development,

$\Omega(t)$ - indicator function with $t \in[0 ; T\}$,

$P_{i}$ - known marginal levels of development of recreational technologies,

$i \in\{1, \ldots n\}$ - set of resort and recreational technologies,

$t_{1}=0 \leq t_{2} \leq \cdots \leq T-$ the final sequence of moments of transitions from one recreational technology to another.

The initial and final conditions are determined from the relations:

$$
\begin{gathered}
x_{1}(0)=x_{0} \geq 0, x_{i}\left(t_{i}\right)=\max \left[x_{0}, x_{i-1},\left(t_{i}-\alpha_{1}\right],\right. \\
i \in\{1, \ldots n\}
\end{gathered}
$$

Moments of time $t_{i}$ correspond to the transition to a new recreational technology, values $\alpha_{1}-$ losses associated with the transition, $u_{i}\left(t_{i}\right)$ - the dynamics of change of resources invested in technology development.

The dynamics $i$ of technology is described by a generalized logistics equation with the growth rate described by the function $f_{i}\left(x_{i}\left(t_{i}\right), u_{i}(t)\right)$, depending on the level already reached at the previous stage of development $x_{i-1}\left(t_{i}\right)$, and the number of resources $u_{i}\left(t_{i}\right)$. The trajectory $x(t)=$ $x_{i}(t), t \in\left[t_{i}, t_{i+1}\right]$, characterizes the dynamics of the level of development of resort and recreational technologies.

Let's determine the level of technology development $X(T)$ by the end of the planned horizon $T$.

$$
X(T)=\max \left[x_{i}(T)\right]
$$

Set the income function $D(X(T))$, reflecting the income received at the end of the planning period and depending on the achieved level of $X(T)$ development of resort and recreational technologies.
Then the income function $F(x(t))=\int_{0}^{T} f(x(t) d t$ shows the income received in the process of technology development, and $Z(u(t))=$ $\int_{0}^{T} \sum_{i=1}^{n} u_{i}(t) e^{-\delta t(t)} d t \quad-\quad$ is the cost functional. $\delta(t) \in[0 ; 1]$ shows the discount rate, $u(t)=\left(u_{1}(t), \ldots, u_{n}(t)\right)$ is a vector of resource dynamics that reflects investment policy, $\Psi=\left(t_{i}=\right.$ $\left.0 \leq t_{2} \leq \cdots \leq T\right)-$ vector of moments of time of change of recreational technologies, which reflects the innovation policy.

Let's introduce the following limitations of the model:

$$
\begin{aligned}
u_{i}\left(t_{i}\right) & \geq z_{i}, u_{i}(t)=0, \\
t & \notin\left[t_{i} ; t_{i+1}\right]
\end{aligned}
$$

where constants $z_{i} \geq 0$ can be interpreted as investments in the implementation of appropriate resort and recreational technologies.

The criterion of efficiency can be formulated as the difference between income and expenses, then the optimization problem will take the form: maximize the criterion of efficiency by choosing a sequence of $\Psi$ changes in technology and resource dynamics vector $u(t)$, that is

$$
D(X(T))+F(x(t))-Z(u(t)) \rightarrow \max
$$

provided that the dynamics of recreational technologies is described by a system of the above equations with given initial conditions, and resources satisfy the constraints.

Each of the equations included in the system can be solved independently

$$
=\frac{x_{i}\left(t, u_{i},(t)\right)}{\left[x_{i}\left(t_{i}\right) \int_{t_{i}}^{t-t_{i}} f_{i}\left(x_{i-1}, u(\tau)\right) e^{\int_{t}^{\tau} f_{i}\left(x_{i-1}, u_{i}(\vartheta)\right) d \vartheta} d \tau+P_{i}\right] e^{-\int_{t_{i}}^{t-t_{i}} f_{i}\left(x_{i-1}\left(t_{i}\right), u_{i}(\vartheta)\right) d \vartheta}}
$$

When $u_{i}(t)=u_{i}, \quad t \in\left[t_{i} ; t_{i+1}\right]$ solving the equation, we obtain a set of logistic curves

$$
x_{i}\left(t, u_{i}\right)=\frac{x_{i}\left(t_{i}\right) P_{i} \Omega\left(t \in\left[t_{i} ; t_{i+1}\right]\right)}{x_{i}\left(t_{i}\right)+\left(P_{i}-x_{i}\left(t_{i}\right)\right) e^{-f_{i}\left(x_{i-1}\left(t_{i}\right), u_{i}(t)\right)}}
$$

It should be noted that in the case of $n \leq 1$, dynamics of development of innovative recreational technologies does not occur and the introduction of innovations is analyzed by traditional methods. The assumption that the planned horizon $T$ is fixed and considered known is the main provision of innovation and investment management and is confirmed by the practical activities of the health economy system.

\section{Simulation results}

The considered optimization model is additive, because in it the criterion of efficiency is the 
difference between the functional from the terminal value of the trajectory and the functional depended on the whole trajectory, and, at the same time, the moments of transitions are a priori ordered. Therefore, this problem can be attributed to the class of optimal control problems with phase coordinates discontinuous at internal points. To solve it, in the case of fixed moments of transitions, dynamic programming methods can be used (Fig. 1, Fig. 2, Fig. 3).

In fig. 1 is shown the optimal solution to the problem of implementing two innovative technologies on the example of the recreational complex of the Northern Priazovye, which demonstrates their effectiveness over the planning horizon and allows to form a strategy for choosing innovation policy. Accordingly, in Fig. 2 is presented the optimal solution to the problem of choosing an innovation policy based on the maximum criterion of efficiency and the vector of resource dynamics.

Thus, the proposed model allows for a joint choice of innovation policy (at what time to start the introduction of a new resort and recreational technology, which includes decisions on the feasibility of its implementation in general) and investment policy - what is the optimal schedule for investment in new recreational technologies.

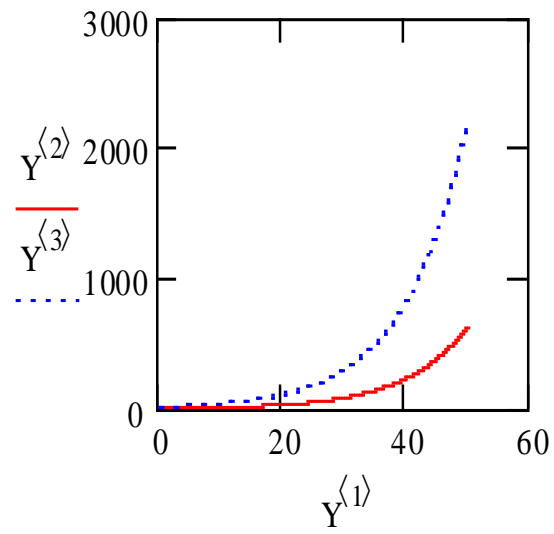

Fig. 1 The optimal solution to the problem of implementing two innovative technologies on the example of the recreational complex of the Northern Priazovye

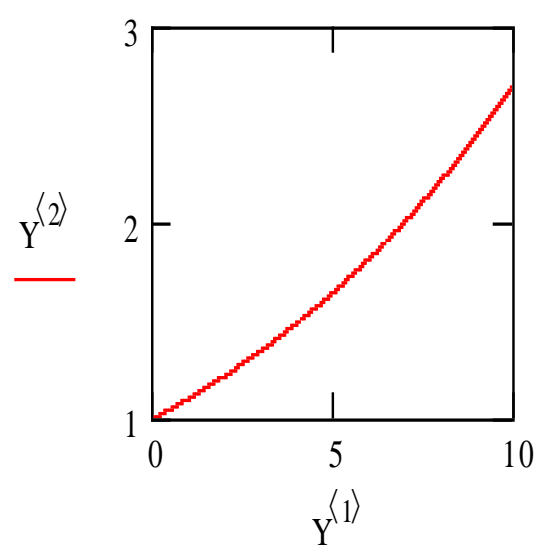

Fig. 2 The optimal solution to the problem of choosing an innovation policy on the example of the recreational complex of the Northern Priazovye

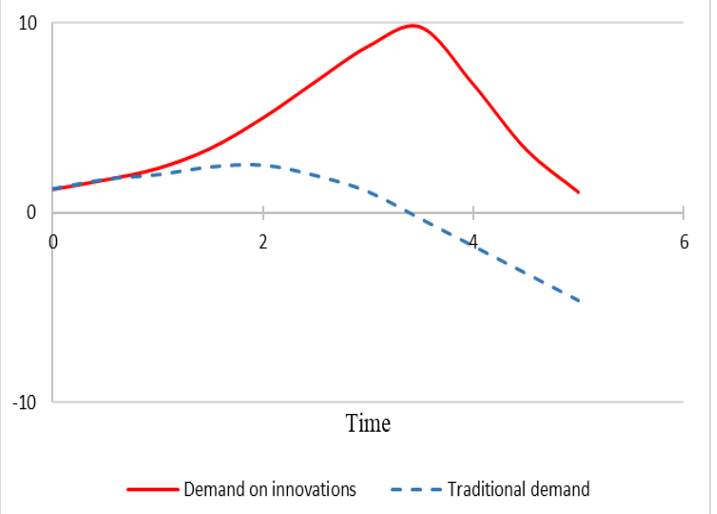

Fig. 3 Demand for innovative and traditional resort and recreational products on the example of the Northern Priazovye (Azov sea)

It should be noted that innovations perform a special function in the reconstitution system - the function of generating changes, they are a source of self-development and self-organization of resort and recreational systems, and they are an important internal process and structural element. To quantify the actions of the reconstitution system, in terms of the existence of input effects, we need to introduce the objective function of the system

$$
F: X \times S \times Y \rightarrow P
$$

where:

$X=\left\{x_{i}\right\} \quad-\quad$ system resources (including innovations);

$S=\left\{s_{i}\right\}, i=\overline{1, N}-$ internal states of the system (production);

$Y=\left\{y_{i}\right\}, i=\overline{1, N}-$ production and sale of resort and recreational products;

$P$ - profit function.

If $P$ has more than one component, then $P=$ $P^{r}=x\left\{P_{i}, i \in I_{r}\right\}$, where $I_{r}=\overline{1, N}$ - number of components (multicriteria system). Let's present the objective function in the form of two functions: the original $W: X \times S \rightarrow Y$ and the function (7). Then 


$$
G(x, p)=F(x, p, W(x, p))
$$

The functional of the equation 8 , which describes the operation of the whole system, is an efficiency functional. Real reconstitution systems usually have several purposes and consist of a set of subsystems. Let's define the local target functions of subsystems as $f_{i}: X_{i} \times Y_{i} \rightarrow P, i \in I$,. Then the functional 4 can be written as $G(x, p)=G(f(x), P)$, where $f(x)=$ $\left\{f_{i}(x), i \in I\right\}$ - quality indicators of subsystems.

Uncertainty is a fundamentally integral part of the innovation process, as innovation is inextricably linked with the struggle between the old and the new. Under uncertainty, the choice of optimal values of system parameters can be carried out as a task of finding satisfactory solutions: you need to find such $\tilde{x} \in X^{\delta}$, that $\forall_{p} \in S$,

$$
G(\tilde{x}, p) \geq \varphi(p)
$$

where $\varphi(p)$ - a function that determines the minimum allowable value of the objective function.

It should be noted that the set $S$ covers both parametric and structural uncertainties, i.e. in fact, it is the set of all factors influencing the solution of problem (9). It should be noted the most important task in the problem (5) is finding a function $\varphi(p)$, which determines the minimum or allowable quality of the system at any manifestations of uncertainty $p \in S$. Function appearance of $\varphi(p)$ depends on both the properties of the function $G(x, p)$, and the type of uncertainty, which takes place depending on the stage of the innovation process. However, uncertainty can be reduced to three main types:

$S^{\langle 1\rangle}$ - the set of uncertainties due to the internal and external environment and their interaction. This type is chaotic in nature and is modeled by the methods of chaos theory and catastrophe theory [28];

$S^{\langle 2\rangle}$ - the set of uncertainty, which is due to purposeful counteraction (competition of systems). It is modeled by methods of game theory [32];

$S^{\langle 3\rangle}$ - the set of uncertainties associated with description inaccuracies that cannot be estimated statistically. It can be described by methods of fuzzy set theory [33].

Thus, the solution of the problem of extended reproduction in the conditions of innovative resortrecreational economy can be obtained on the basis of the model of multicriteria optimization taking into account the above relations.

It should be noted that the proposed approach and developed models in terms of practical application are a powerful and effective means of analyzing the formation of innovative policy of resort and recreational organizations. They give the approach to practical application of health economic system in a competitive market and contribute to the competitiveness of both resort and recreational product and national health complex as a whole.

\section{Discussion}

Innovative activity in the resort and recreational economy is explained by two hypotheses [34]. According to the first one - the basis of innovation and innovation process is a technological push, and from the point of view of the second hypotheses the pressure of market demand. The hypothesis of technological impetus is based on the idea of autonomous development of science, which does not attach importance to the feedback between the economic environment and the direction of technological progress.

In the second hypothesis, the formation of the need for innovation is mediated by the need for economic agents to compare the amount of resources used (total costs) for innovation with the results of their using development of the resort and recreational industry. The ratio of results and costs, which determines the implementation of innovative activities, occurs in the following situations:

supply and demand are equal - the source of profit is the reduction of the cost of resort activities, and innovations are used by resort and recreational complexes insufficiently to maximize profits;

excess of demand over supply, which leads to the attraction of reserves and innovations in resort activities and the growth of additional costs, which are covered by an increase in the production of resort and recreational products and their sales;

demand is lower than supply - means and funds for innovation are reduced, inefficient factors of resort activities are removed from circulation through their conservation. The optimal level of profit is restrained only by reducing costs.

Thus, innovations are actively involved in resort and recreational activities only when the growth of demand requires a sharp increase in the production of resort and recreational products, i.e. the priority for innovation is economic conditions. Thus, the hypothesis of market demand links the growth of innovative opportunities of the resort and tourism economy with market demands.

In the conclusion of the analysis of the importance of innovations in the resort and recreation, we should focus on the next insufficiently studied problem. Most theories of economic development that exist today assign the main organizing role to exogenous factors of a market economy that ensure economic growth. At the same time, J. Schumpeter was one of the first to 
show the importance of endogenous factors of economic development, thereby introducing such a temporal principle as discreteness. The main driving force of development, according to Schumpeterian theory, is the innovation process. In this approach, the process of economic development has the principle of discreteness, rather than continuity, as assumed by default in most studies on development [35]. Thus, the innovative development of the economy recognizes two important principles: first one - the presence of internal chaotic processes inherent in the emergence of innovation and the second principle - the discrete nature of innovation processes.

Hence, with regard to the resort and recreational economy, we can conclude that the functioning of such an economy has the principle of continuity, and its development has the principle of discreteness. In our understanding, the discreteness of the development of the resort and tourist economy is the principle of development of the recreational system, in which its development is characterized by distinct long periods of time in which the system operates in relatively stable states; while the transition between these states is abrupt. This abrupt transition in the development of the resort and tourism economy is a discrete leap, which should be understood as the transition through unstable states to a stable economy at the highest quality level, i.e. the transition from chaos to order. The reason for discrete changes is the emergence and application of innovations.

Thus, there are certain time intervals - turning points in which there is a discrete jump - the transition from one state to another. In such time periods, new technological and economic opportunities appear, the implementation of which causes the transition to a new great wave of development. The uneven emergence of new technological revolutions in space, as well as abrupt discrete transitions from one big wave of development to another one indicates the discreteness and unevenness of the development process. At the same time, in a traditional economy there may be pauses in the deployment of a new big wave - "innovation pauses" - which can cause economic crises.

\section{Conclusions}

In conclusion, based on the results of modelling and analysis, we can draw the following conclusions about the patterns of innovation processes in the resort and recreational economy, and in the national health economy as a whole.
1. Periodic innovative changes are a general pattern of the economy as a whole and the resort and recreational economy in particular. This is due to three circumstances. Firstly, any system has its own development potential and life cycle, and the transition from phase to phase requires changes. Secondly, the resort-recreational economy itself has a general tendency to increase and complicate, increase the volume and differentiate the structure of needs, which need to be met, each system must be improved. Third, the natural environment is also subject to change, and the resort and recreational economy must undergo changes in order to adequately respond to these external actions. If the economy (or any of its components) loses the ability to change, it is often at the root of crises that culminate in economic transformations. Changes are not continuous, they are followed by a period of uniform development until the potential of this state and its evolutionary improvement is exhausted.

2. Innovation activity carried out cyclically, waves of innovation activity were replaced by recessions. In the development of the health economy and its component part, the resort and recreational industry, there are clear innovation cycles of varying depth and duration. At critical periods in the dynamics of this industry, a wave of disruptive innovations rises, which generates a flow of innovations that improve and partially correct the major innovations made. After that, the number of disruptive innovations decreases, but it is repeatedly overlapped by the growing number of various business-improving innovations that have a significant effect on the updated system. In the third phase of the cycle, innovation activity stabilizes, but its structure deteriorates: disruptive innovations virtually cease, improving innovations become smaller and less effective, there are pseudoinnovations aimed at partially improving and prolonging the life of the basically obsolete, doomed to radical system transformation. In the next phase of the innovation crisis, the level of innovation activity falls sharply, the share of pseudo-innovation increases. In the phase of depression, innovation activity is at a low level, at the same time the preconditions for the next wave of disruptive innovations are created, and the spiral of changes enters the next round, a new innovation cycle begins.

3. In the dynamics of innovation activity, there is an interaction of innovation cycles of different duration, as well as their interaction with the cyclical dynamics of other sectors of the economy.

Innovation cycles vary in duration and depth. The most massive innovations are made when 
changing short-term cycles. When generations of technologies change, the underlying disruptive innovations are realized, and innovation waves are observed within the framework of a ten-year cycle. These waves, in turn, are superimposed on the upward or downward waves of long-term cycles. On the rising wave, the height and duration of innovative ups are more significant, the downs less. On the downward wave of the long-term cycle, the opposite pattern is observed. However, the longest periods of profound changes are observed when the longest cycles change. Waves of disruptive innovations lead to the formation of new technological and economic methods of production.

Another section of the interaction of cycles - the mutual influence of innovation cycles in related areas of the economy. For example, cyclical fluctuations of technological innovations are associated with the dynamics of scientific and inventive cycles, reflect their trajectory and, in turn, determine the trajectory of economic and environmental cycles. All these areas are based on their own dynamics of innovation cycles. Therefore, it is possible to speak about regularity of interrelation of innovative changes in various spheres of economy having the general rhythm of fluctuations. Also, when studying the interaction of the cyclical dynamics of innovation, it should be borne in mind that this interaction can be carried out in three main forms: resonant, damping and deforming.

For example, the declining wave of long-term and long-term cycles has an amplifying, resonant effect on the fluctuations of the parameters of medium-term crises that fall into this phase. The inverse, damping (softening) effect is exerted by the ascending wave of Kondratiev cycles. Some crises can have a distorting effect on the course of the innovation cycle, i.e. interrupt and distort its further course, sharply reduce the cost of innovation and its number.

4. Waves of innovative activity are unevenly distributed in space, their epicentres and leaders of innovative activity periodically change. Epochmaking and disruptive innovation are associated with large investments in the transformation of socio-economic systems and require the accumulation in a narrow space of the preconditions and conditions of such processes, which then spread throughout the world economy. Each innovation revolution has its starting point (epicentre). The initiator of the coup is one or more leading industries that have just emerged or radically transformed. At the epicentre can be concentrated the primary sources of innovative economic renewal.

\section{References:}

[1] Romanova G.M., Strategicheskoe planirovanie razvitija kurortov $i$ turizma $v$ regione, Izd-vo SPbGUJeF, 2018.

[2] Bokov M., Strategic management of recreational enterprises in conditions of transitional economy, National Institute for Strategic Studies, 2011.

[3] Mamatova T.V., Chykarenko I.A., Moroz E.G., Yepifanova I.Y., Kudlaieva N.V. Management of enterprises and organizations under the conditions of sustainable development. International Journal of Management, 11(4), 2020, pp. 151-159.

[4] Makaryicheva E.A., Razvitie rekreatsii v sootvetstvii $\mathrm{s}$ kontseptsiey ustoychivogo razvitiya, Ekologiya $i$ zhizn, No.IV, 2017, pp. 19-28.

[5] Amirkhanov M., Tatarinov A., Economic problems of development of recreation regions, Helios, 2017.

[6] Voynarenko M, Dzhedzhula V., Hurochkina V., Yepifanova I., Menchynska, O. (2021). Applying Fuzzy Logic to Modeling Economic Emergence WSEAS Transactions on Business and Economics, 18, 424-433.

[7] Heyets V., Voynarenko M., Dzhedzhula V., Yepifanova I. \& Trocikowski T. (2021) Models and strategies for financing innovative energy saving activities, IOP Conf. Series: Earth and Environmental Science, 628, 012004, doi:10.1088/1755-1315/628/1/012004.

[8] UNWTO Homepage, http://www.unwto.org/index.php, last accessed 2021/03/29.

[9] Nestorenko T., Budnyk V., Dubrovina N., Tokarenko O., Ursakii Yu., Economic Impact of Health Resort Enterprises for the Host City: Case Study from Ukraine, Empowering Actions to Achieve Global Goals: Implications for Economics, Business, Management and Related Disciplines. Conference Proceedings of International Scientific Conference for Doctoral Students and Post-Doctoral Scholars, 2020, pp. 366-372.

[10] Hrapyilina L.P., Hryakov V.V., Bochkarev A.U., Ekonomika $i$ upravlenie razvitiem $\mathrm{ku}$ rortov, Drofa, 2020.

[11] Pakakov M., Zhyndrov P., Determinantyi neravenstva $\mathrm{V}$ otnoshenii zdorovya $\mathrm{v}$ 
evropeyskih stranah, Operatsii WSEAS po biznesu i ekonomike, No.IV, 2019, pp. 25-38.

[12] Shumpeter J., Teorija jekonomicheskogo razvitija, Eksmo, 2018.

[13] Kondratev N.D., Bolshie cikly konjunktury $i$ teorija predvidenija, Ekonomika, 2012.

[14] Prokopenko O., Omelyanenko V., Tirto T., Security issues of system innovation strategies. SHS Web of Conferences, Vol. 65, 2019, https://www.shsconferences.org/articles/shsconf/abs/2019/06/c ontents/contents.html, last accessed 2021/06/05.

[15] Mensh G., Tehnologicheskij pat: innovacii preodolevajut depressiju, http://www.russtrategy.ru/training/lecturers/me nsch, last accessed 2021/03/29.

[16] Kleinknest A., Innovation patterns in crisis and prosperity: Shumpeter's long cycle reconsidered, Methuen, 1997.

[17] Kuznec S., Jekonomicheskij rost nacij: sovokupnyj vypusk $i$ proizvodstvennaja struktura, Nauka, 2000.

[18] Coomns R., Kleinknest A., New evidence on the shift toward process innovation during the long-wave upswing, Design, innovation and long cycles in economic development, No.I, 2017, pp. 11-29.

[19] Freeman C., Unemployment and Technique Innovation, London, 1992.

[20] Petersone M., Ketners K., Krievinsh D., Erins I., Strategicheskie zakupki i effektivnost sistemyi zdravoohraneniya: perspektivyi reformyi sektora zdravoohraneniya v Latvii, Operatsii WSEAS po biznesu i ekonomike, Vol.XVII, 2020, pp. 41-50.

[21] Vyalykh N.A., Bespalova A.A., Mental Programs and Models of Medical Care Consumption in a Multicultural Region of the South of Russia. Public Administration and Regional Management in Russia. Contributions to Economics, Springer, 2020.

[22] Langlois R., Everett M., What is Evolutionary Economics?, Evolutionary Neo-Schumpeterian Approach to Economics, No.I, 2014, pp. 11-48.

[23] Enthoven A.C., Market forces and efficient health care systems, Health Affairs, No.XXII, pp. 25-27.

[24] Berdine G., Uncertainty and the welfare economics of medical care: an Austrian rebuttal Part 2, The Southwest Respiratory and Critical Care Chronicles, No.VI(XVII), 2017, pp. 6367.
[25] Grignon M., Hurley J., Feeny D., Guindon E., Hackett C., Moral Hazard in Health Insurance, Economia, No.III, 2018, pp. 367-405.

[26] Cartright R., Strategies for hypergrowth, Capstone Publishing, 2018.

[27] Yepifanova I., Dzhedzhula V. Modelling of Potential Level of Industrial Enterprises. WSEAS Transactions on Environment and Development, Vol. 17, 2021, pp. 556-565

[28] Lazutin H.I., Formy, metody ta instrumenty realizatsii innovatsiinoi polityky, Aktualni problemy ekonomiky, No.VI, 2003, pp. 50-57.

[29] Thomson. S., Dixon A., Choices in health care: the European experience, Journal of Health Services Research \& Policy, No.XI(III), 2016, pp.167-171.

[30] Novickij N.A., Innovacionnaja jekonomika. Teoretiko-metodologicheskie osnovy $i$ strategicheskie prioritety, Librokom, 2019.

[31] Carkov V.A., Dinamicheskie modeli jekonomiki. Teorija i praktika jekonomicheskoj dinamiki, Ekonomika, 2017.

[32] Karpova E.G., Upravlenie innovacijami s primeneniem teorii igr, Regionologija, No.III, 2019, pp. 57-67.

[33] Ravenscroft N., Recreation Planning \& Development, McMillan, 2017.

[34] Heertje A., Schumpeter on the Economics of Innovation and the Development of Capitalism, Edword Elgar, 2016.

[35] Ramazanov S., Tishkov B., Chernyak O., Nonlinear forecasting of the state of a socio-ecooriented innovative economy in the context of systemic crises, Experimental Economics and Machine Learning for Prediction of Emergent Economy Dynamics, Vol.2422, 2019, pp.181193.

\section{Creative Commons Attribution}

\section{License 4.0 (Attribution 4.0 \\ International , CC BY 4.0)}

This article is published under the terms of the Creative Commons Attribution License 4.0 https://creativecommons.org/licenses/by/4.0/deed.en US 